\title{
The comparison of trans-septal suture, Merocel nasal packing and septal splint following septoplasty combined with inferior turbinate surgery
}

\author{
Septoplasti ile kombine inferior turbinat cerrahileri sonrası trans-septal sütür, \\ nazal tampon ve nazal splint karşılaştırmast
}

Arzu Tatar, ${ }^{1}$ Özgür Yörük, ${ }^{1}$ Zahide Koşan, ${ }^{2}$ Fatma Atalay ${ }^{1}$

${ }^{1}$ Department of Otolaryngology, Medical Faculty Atatürk Universikty, Erzurum, Turkey

${ }^{2}$ Department of Public Health, Medical Faculty Atatürk Universikty, Erzurum, Turkey

\begin{abstract}
Objectives: This study aims to investigate the efficacy of nasal splint, Merocel nasal packing and trans-septal suturing applications in septoplasty combined with inferior turbinate surgeries in the prevention of postoperative pain and complications.

Patients and Methods: Between January 2014 and October 2015 a total of 180 patients ( 129 male, 51 female; mean age $31.32 \pm 10.27$ years; range 18 to 55 years) for which septoplasty concurrent with inferior turbinate surgery was planned were included in this study. Following septoplasty, patients were divided into two equal groups to apply Radiofrequency Thermal Ablation (RFTA) and Partial Inferior Turbinectomy (PIT). Both patient groups were separated into three subgroups in themselves to apply nasal splint, Merocel packing and trans-septal suturing, so that each group would have 30 patients. The duration of surgery, minor and major hemorrhage, postoperative pain evaluated at the $6^{\text {th }}$ hour, on the $1^{\text {st }}, 2^{\text {nd }}$ and $3^{\text {rd }}$ day, and postoperative complications in the $6^{\text {th }}$ week (septal perforation, hematoma, infection, crusting, nasal synechiae) were compared.

Results: There was no statistical difference in research parameters except for the postoperative pain in three subgroups applied splint, Merocel packing, and trans-septal suture after RFTA concurrent with septoplasty surgery. Although nasal synechia developed in five patients who were applied Merocel packing, in six patients who were applied trans-septal suture and in one patient who was applied splint in the group in which PIT was performed, the difference between synechiae and other research parameters was statistically insignificant. The highest level of postoperative pain was determined in the Merocel packing groups, and the lowest level was determined in the groups that were applied trans-septal suture at the groups in which splint, Merocel packing, and trans-septal suture were applied.

Conclusion: The preference of splint use in septoplasty combined with PIT surgeries to Merocel packing and the preference of trans-septal suture application in septoplasty combined with RFTA surgeries to Merocel nasal packing will contribute to the prevention of pain, discomfort and complications caused by Merocel packing and to providing patients with a more comfortable postoperative period.
\end{abstract}

Keywords: Merocel nasal packing; nasal splint; partial inferior turbinectomy; radiofrequency thermal ablation; septoplasty; trans-septal suture.

\section{$\ddot{O} Z$}

Amaç: Bu çalışmada septoplasti ile kombine inferior turbinat cerrahilerinde, nazal splint, Merocel nazal tampon ve trans-septal sütür uygulamalarının ameliyat sonrası ağrı ve komplikasyonları önlemedeki etkinlikleri araştırıldı.

Hastalar ve Yöntemler: Ocak 2014 - Kasım 2015 tarihleri arasında, çalışmaya septoplasti ile birlikte inferior turbinat cerrahisi planlanan 180 hasta (129 erkek, 51 kadın; ort. yaş $31.32 \pm 10.27$ yıl; dağılım $18-55$ yıl) dahil edildi. Septoplastiyi takiben Radyofrekans Termal Ablasyon (RFTA) ve Parsiyel İnferior Turbinektomi (PİT) uygulanmak üzere hastalar iki eşit gruba ayrıldı. Her iki hasta grubu da kendi içinde, her grupta 30 hasta olacak şekilde, nazal splint, Merocel tampon ve trans-septal sütür uygulamak üzere üç alt gruba daha ayrıldı. Cerrahi süresi, minör ve majör hemoraji, ameliyat sonrası 6 . saat, 1,2 . ve 3. günlerde değerlendirilen ağrı ve ameliyat sonrası 6 . haftada görülen komplikasyonlar (septal perforasyon, hematom, enfeksiyon, kabuklanma ve nazal sineşi) ile karşılaştırıldı.

Bulgular: Septoplasti ile eşzamanlı yapılan RFTA sonrası splint, Merocel tampon ve trans-septal sütür alt gruplarında, ameliyat sonrası ağrı hariç diğer araştırma parametrelerinde istatistiksel farklılık yoktu. Parsiyel inferior turbinektomi yapılan grupta Merocel tampon uygulanan beş, trans-septal sütür uygulanan altı, splint uygulanan bir hastada nazal sineşi gelişmesine rağmen sineşi ve diğer araştırma parametreleri arasındaki fark istatistiksel olarak anlamlı bulunmadı. Splint, trans-septal sütür ve Merocel tampon uygulanan gruplarda, ameliyat sonrası ağrı düzeyi en yüksek tampon gruplarında ve en düşük trans-septal sütür gruplarında tespit edildi.

Sonuç: Septoplasti ile kombine RFTA cerrahilerinde trans-septal sütür uygulamasının, septoplasti ile kombine PİT cerrahilerinde ise splint kullanımının nazal tampon uygulamasına tercih edilmesi, tamponun neden olduğu ağrı, rahatsızlık ve komplikasyonların engellenmesine ve hastalara daha konforlu ameliyat sonrası dönem sunulmasına katkı sağlayacaktır.

Anahtar sözcükler: Merocel nazal tampon; nazal splint; parsiyel inferior türbinektomi; radyofrekans termal ablasyon; septoplasti; trans-septal sütür. 
Septal deviation is one of the common causes of nasal obstruction. Deviation of the nasal septum towards a nasal cavity leads to the development of compensatory inferior turbinate hypertrophy in the opposite nasal cavity. Therefore, septoplasty and inferior turbinate surgery are surgical procedures that are frequently applied together. ${ }^{[1]}$ Numerous surgical techniques have been described for the treatment of inferior turbinate hypertrophy. Among these techniques, Radiofrequency Thermal Ablation surgery (RFTA) is a minimally invasive and effective treatment that protects nasal physiology and does not require packing. Partial Inferior Turbinectomy (PIT) is a more invasive technique that provides effective turbinate reduction but causes more mucosal damage and hemorrhage compared to RFTA. ${ }^{[2]}$

Septoplasty may result in complications such as hemorrhage, septal hematoma, infection, septal perforation, septal abscess and nasal synechiae development. ${ }^{[1]}$ Nasal packing, nasal septal splints or trans-septal suturing techniques are used to prevent these complications and to ensure the internal stabilization of nasal bone and cartilage skeleton following surgery ${ }^{[1,3]}$ Nasal packing may lead to complications such as mucosal injury, loss of ciliary function, worsening of breathing due to sleep disorders, displacement and aspiration of the packing material, allergy, toxic shock syndrome, postoperative infections and eustachian tube dysfunction. ${ }^{[1,3,4]}$ In addition, nasal pack application following nasal surgery requires hospitalization until the pack is removed and causes more pain compared to that caused by surgery postoperatively and during the process of pack removal.

Taking all the above factors into account, it has been suggested that packing may prolong the healing process, increase the costs of hospitalization and prolong the period of workforce loss. ${ }^{[4]}$ Therefore, nasal packing--commonly used after septoplasty and inferior turbinate surgeries and even considered one of the basic steps of surgery--has increasingly been replaced by the use of nasal splints and suture techniques. Clinical studies have demonstrated that nasal septal splints and trans-septal suturing after septoplasty caused less postoperative pain but similar results in the prevention of postoperative complications compared to packing. ${ }^{[3-6]}$ Other researchers have suggested that they are superior to packing in the prevention of nasal synechiae and postoperative hemorrhage. ${ }^{[7,8]}$

Numerous studies have compared the effects of sutures, splints and packing on postoperative complications following septoplasty. ${ }^{[3-6]}$ However, not much emphasis was put on which application was more effective in preventing postoperative complications after combined septoplasty and inferior turbinate surgery and a consensus has yet to be reached in this regard. It is well known that multiple nasal surgeries increase the risk of postoperative pain, hemorrhage, and nasal synechia development. Thus, in this study, we aimed to compare the effects of polyvinyl alcohol sponge (Merocel ${ }^{\circledR}$ ) nasal packing, septal splints and trans-septal suturing on postoperative pain levels and the prevention of postoperative complications in patients after septoplasty and RFTA or PIT surgery.

\section{PATIENTS AND METHODS}

This prospective, randomized study was approved by the Ethics Committee of the Ataturk University Medical Faculty and written informed consent was obtained from each patient. The study was conducted in accordance with the principles of the Declaration of Helsinki.

A total of 180 patients (129 males, 51 females; mean age $31.32 \pm 10.27$ years; range 18 to 55 years) with septal deviation and compensatory inferior turbinate hypertrophy for whom septoplasty with concurrent inferior turbinate surgery was planned were included in this study. Patients with paranasal sinus pathology, systemic disease, and previous nasal surgery history were excluded. The patients were randomly divided into two groups using block randomization method to undergo either RFTA or PIT after septoplasty, with RFTA ( $\mathrm{n}=90)$ and PIT $(n=90)$. The patients in both groups were then randomly divided into three subgroups of 30 patients each, forming a total of six study groups: Group RP, Merocel ${ }^{\circledR}$ packing after septoplasty and RF; Group RS, nasal splint after septoplasty and RF; Group RT, trans-septal suture after septoplasty and RF; Group PP, Merocel ${ }^{\circledR}$ packing after septoplasty and PIT; Group PS, nasal splint after septoplasty and PIT application; and Group PT, transseptal suture after septoplasty and PIT.

The pain levels of the patients at the postoperative sixth hour, and the first, second and third days were evaluated using a visual analog scale from 0 to 4 (no pain, 0; mild, 1; moderate, 2; severe, 3; most severe, 4). At the same time (time-point of the study), patients were evaluated in terms of major and minor hemorrhage. Mild postoperative nasal secretions containing blood were not evaluated as hemorrhage. Blood leakage was considered as minor hemorrhage in the case of cessation with $0.1 \%$ adrenaline-soaked cotton swabs application, and as major hemorrhage in cases where nasal packing was required. The patients were also asked to report any hemorrhage in the following six weeks. Six weeks after surgery, the patients were evaluated in terms of complications such as hematoma, perforation, synechiae and crusting, and infection. 
All surgical procedures were performed by the senior author under general anesthesia. Septoplasty was performed in all patients using the same operative technique. After local infiltration, a hemitransfixion incision was performed on the concave side of the nasal septum. The mucoperichondrial and mucoperiosteal flaps were elevated according to the location of pathology. The deviations of the cartilage were corrected with excisions or sutures conserving the L-strut support, and deviations of the bone were corrected by excisions. Excessive septal parts such as crests and spurs were trimmed. Surgical incisions were sutured with 4/0 Vicryl (Sutures limited, Wrexham UK). Septoplasty was followed by PIT or RFTA.

Temperature-controlled radiofrequency thermal ablation (Surgitron; Ellman International, Inc., Hewlett, New York, USA) was used for RFTA surgery. The radiofrequency electrode was inserted submucosally, assisted by a $0^{\circ}$ endoscopic view. Radiofrequency energy was applied to the anterior, middle, and posterior portions of the inferior turbinate, at 10 to $15 \mathrm{~W}$, for 15 seconds. Partial inferior turbinectomy was performed assisted by a $0^{\circ}$ endoscopic view. After medialization, inferior turbinates (including mucosa and part of the bone) were trimmed at different levels depending on the degree of hypertrophy using angled turbinectomy scissors. Hemostasis was secured in all patients by applying $0.1 \%$ adrenaline-soaked cotton swabs. Following both inferior turbinate surgeries, Meroce ${ }^{\circledR}$ nasal packing, splint, or trans-septal suture was applied according to the previously-randomized groups.
Nasal packing utilized polyvinyl sponge Merocel ${ }^{\circledR}$ nasal dressing (Invotec International, Inc., 6833 Phillips Industrial Boulevard Jacksonville, FL, USA), removed in the morning of the second postoperative day. One millimeter thick silicone nasal splints (Boston Medical Products, Westborough, MA, USA) were used for nasal splint application, and these were fixed by suturing to nasal septum with. They were removed after one week. Trans-septal sutures were placed horizontally, vertically, or obliquely through the elevated regions of nasal septum using 4/0 Vicryl Rapide (Sutures limited, Wrexham UK).

All patients were hospitalized overnight postoperatively and were given amoxicillin/clavulanate $1000 \mathrm{mg}$ p.o. twice a day for one week. Isotonic seawater sprays for nasal lavage were started from the first day in the trans-septal suturing and splint groups and after the second day following pack removal in the Merocel ${ }^{\circledR}$ groups.

\section{Statistical analysis}

Data entry and statistical analysis were performed using IBM-SPSS for Windows version 20.0 software (IBM Corporation, Armonk, NY, USA). Categorical variables were expressed as number and percentage, numeric variables, mean and standard deviation. The Independent samples $t$ test was used for comparison of age and operation time in data analysis; the chi-square test of nonparametric tests was used for categorical data; the Kruskal-Wallis test was used for multiple comparisons; the Mann-Whitney U test was used for paired comparisons. The significance level was set at $\mathrm{p}<0.05$.

\begin{tabular}{|c|c|c|c|c|c|}
\hline \multicolumn{6}{|c|}{$\begin{array}{l}\text { Demographic distribution and the frequency of complication between radiofrequency thermal ablation and } \\
\text { partial inferior turbinectomy applying groups concurrent with septoplasty }\end{array}$} \\
\hline & \multicolumn{2}{|c|}{ Radiofrequency } & \multicolumn{2}{|c|}{ Partial inferior turbinectomy } & \multirow[b]{2}{*}{$p$} \\
\hline & $\mathrm{n}$ & Mean \pm SD & $\mathrm{n}$ & Mean \pm SD & \\
\hline Age (years) & & $30.78 \pm 10.01$ & & $31.85 \pm 10.53$ & 0.488 \\
\hline Sex & & & & & 0.906 \\
\hline Male & 64 & & 65 & & \\
\hline Female & 26 & & 25 & & \\
\hline Operating time (min) & & $49.35 \pm 10.08$ & & $57.83 \pm 9.56$ & 0.000 \\
\hline Minor hemorrhage & 2 & & 9 & & 0.026 \\
\hline Major hemorrhage & 0 & & 2 & & 0.155 \\
\hline Crusting & 9 & & 26 & & 0.001 \\
\hline Synechiae & 1 & & 12 & & 0.003 \\
\hline Perforation & 1 & & 0 & & 0.321 \\
\hline Hematoma & 1 & & 0 & & 0.321 \\
\hline
\end{tabular}




\section{Table 2}

Demographic distribution and the frequency of complication between Merocel packing, suture and splint applying groups following radiofrequency thermal ablation surgery performed concurrent with septoplasty

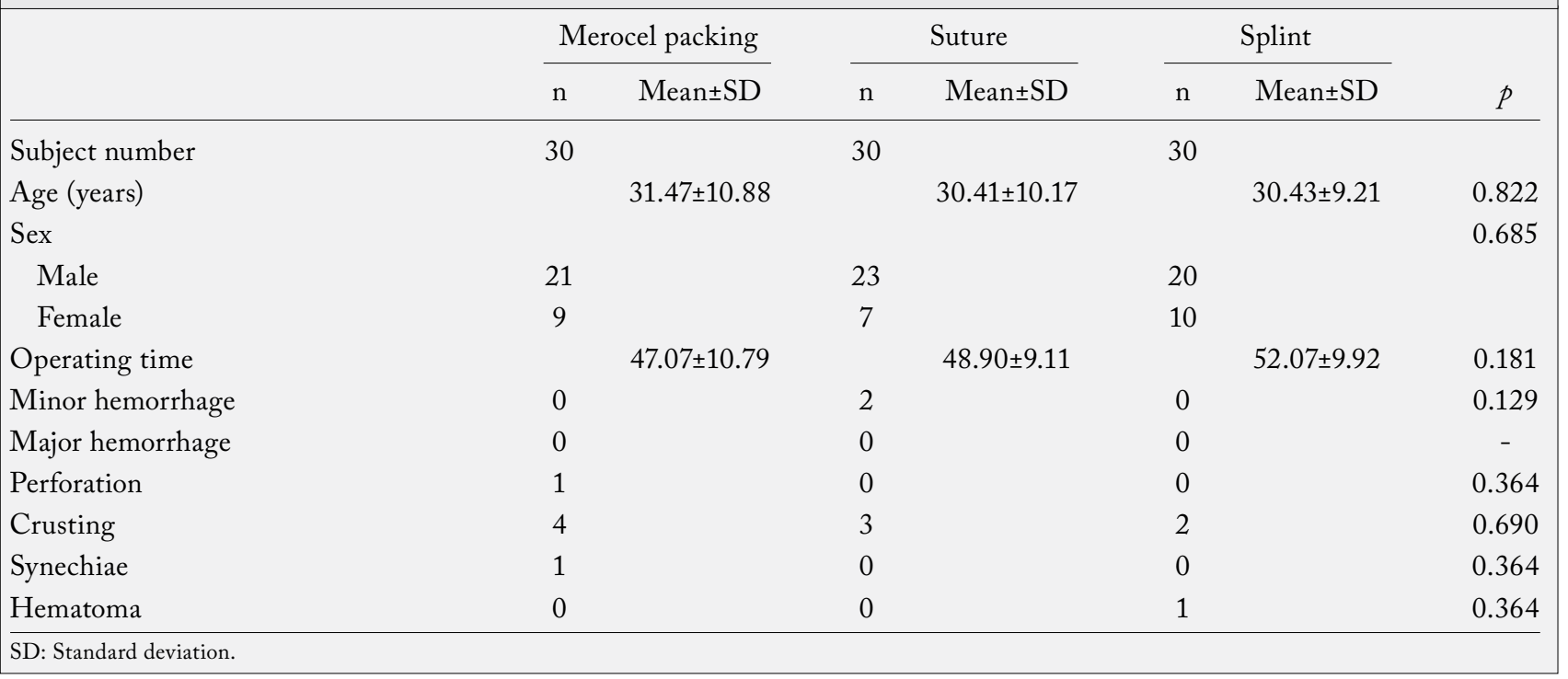

\section{RESULTS}

There was no statistical difference between all study groups in terms of age and sex ( $p>0.05)$. (Table 1, 2 and 3) The operative time was $49.35 \pm 10.08 \mathrm{~min}$ in the RFTA group, and $57.83 \pm 9.56 \mathrm{~min}$ in the PIT group, and the difference was statistically significant $(p=0.000)$. The highest pain scores were observed in the PIT group for all working time-points of the study. (Table 4 and
Figure 1) While the difference between pain scores in the sixth postoperative hour $(\mathrm{p}<0.049)$ and on the first day $(\mathrm{p}<0.027)$ was statistically significant, the difference between pain scores on the second and third days was statistically insignificant. Statistically significant minor hemorrhages were observed more in the PIT groups $(p<0.026)$. Major hemorrhage occurred in two patients in the PIT group after removal of Merocel ${ }^{\circledR}$ packs on the second postoperative day, and these patients were

Table 3

Demographic distribution and the frequency of complication between Merocel packing, suture and splint applying groups following partial inferior turbinate surgery performed concurrent with septoplasty

\begin{tabular}{|c|c|c|c|c|c|c|c|}
\hline & & cel packing & & Suture & & Splint & \\
\hline & $\mathrm{n}$ & Mean \pm SD & $\mathrm{n}$ & Mean \pm SD & $\mathrm{n}$ & Mean \pm SD & $p$ \\
\hline Subject number & 30 & & 30 & & 30 & & \\
\hline Age (years) & & $29 \pm 9.35$ & & $33.23 \pm 10.65$ & & $32.20 \pm 11.22$ & 0.822 \\
\hline Sex & & & & & & & 0.679 \\
\hline Male & 23 & & 22 & & 20 & & \\
\hline Female & 7 & & 8 & & 10 & & \\
\hline Operating time & & $54.63 \pm 9.67$ & & $57.27 \pm 9.85$ & & $60.47 \pm 8.67$ & 0.063 \\
\hline Minor hemorrhage & 1 & & 5 & & 3 & & 0.129 \\
\hline Major hemorrhage & 2 & & 0 & & 0 & & 0.227 \\
\hline Perforation & 0 & & 0 & & 0 & & - \\
\hline Crusting & 12 & & 7 & & 7 & & 0.259 \\
\hline Synechiae & 5 & & 6 & & 1 & & 0.133 \\
\hline Hematoma & 0 & & 0 & & 1 & & 0.364 \\
\hline
\end{tabular}




\section{Table 4}

Postoperative visual analog scale scoring of radiofrequency and partial inferior turbinate groups at all times studied

\begin{tabular}{|lcccc|}
\hline & \begin{tabular}{c} 
Radiofrequency \\
\cline { 5 - 5 }
\end{tabular} & & $\begin{array}{c}\text { Partial inferior } \\
\text { turbinectomy }\end{array}$ & \\
\cline { 2 - 2 } & Mean \pm SD & & Mean $\pm S D$ & $p$ \\
\hline $6^{\text {th }}$ hour & $1.94 \pm 0.76$ & & $2.15 \pm 0.65$ & 0.049 \\
$1^{\text {st }}$ day & $1.37 \pm 0.64$ & & $1.59 \pm 0.63$ & 0.027 \\
$2^{\text {nd }}$ day & $0.70 \pm 0.42$ & & $0.67 \pm 0.39$ & 0.851 \\
$3^{\text {rd }}$ day & $0.10 \pm 0.05$ & & $0.17 \pm 0.08$ & 0.169 \\
\hline SD: Standard deviation. & & & \\
\hline
\end{tabular}

excluded from the study, as pack reapplication was required. A septal hematoma developed in one patient in whom RFTA was performed and splints were applied; this patient was also excluded from the study. Postoperative nasal synechiae $(\mathrm{p}=0.003)$ and crusting $(\mathrm{p}=0.001)$ levels were found more in the PIT groups compared to the RFTA groups; these were statistically significant. The difference in terms of perforation and hematoma development was statistically insignificant in both groups (Table 1).

Operative times were $47.07 \pm 10.79 \mathrm{~min}, 48.90 \pm 9.11$ min, and $52.07 \pm 9.92 \mathrm{~min}$ respectively in the RP (Merocel $\left.{ }^{\circledR}\right)$, RT (trans-septal suture) and RS (splint) subgroups of the RFTA group, and $54.63 \pm 9.67 \mathrm{~min}$, $57.27 \pm 9.85 \mathrm{~min}$, and $60.47 \pm 8.67 \mathrm{~min}$ respectively in the PP (Merocel $\left.{ }^{\circledR}\right)$, PT (trans-septal suture) and PS (splint) subgroups of the PIT group.
Although suture application had the longest operative time in both groups, the difference between groups was statistically insignificant $(\mathrm{p}<0.05) \quad($ Table 2 and 3 ). Minor hemorrhage developed in two patients in the RT (transseptal suture-RFTA) groups. There was no statistical difference between Meroce ${ }^{\circledR}$ packing, splints and sutures in terms of major and minor hemorrhage in septoplasty with RFTA patients. In this group, perforation developed in one patient, and nasal synechia developed in another patient with Merocel ${ }^{\circledR}$ packing; while septal hematoma developed in a patient with splint application. Among the RFTA groups, there was no statistical difference between sutures, Merocel ${ }^{\circledR}$ packing and splint application in terms of perforation, crusting, synechiae, and hematoma development (Table 2).

In the PIT groups, minor hemorrhage developed in a patient and major hemorrhage developed in two patients after removal of Merocel ${ }^{\circledR}$ packing, minor hemorrhage developed in three patients with splint and in five patients with trans-septal sutures on the first postoperative day. Although the number of patients in whom minor hemorrhage developed was greater in the PT (trans-septal suture PIT) group compared to the two other applications, the difference was statistically insignificant. Nasal synechiae developed in five patients with Merocel ${ }^{\circledR}$ packing, in six patients with sutures, and only one patient with splints. Although synechiae development was lower in the splint-applied group, the difference between the groups was not statistically significant. Finally, a septal hematoma developed in one patient with nasal splints. Among the PIT groups, there was no statistical difference between Merocel $^{\circledR}$ packing,

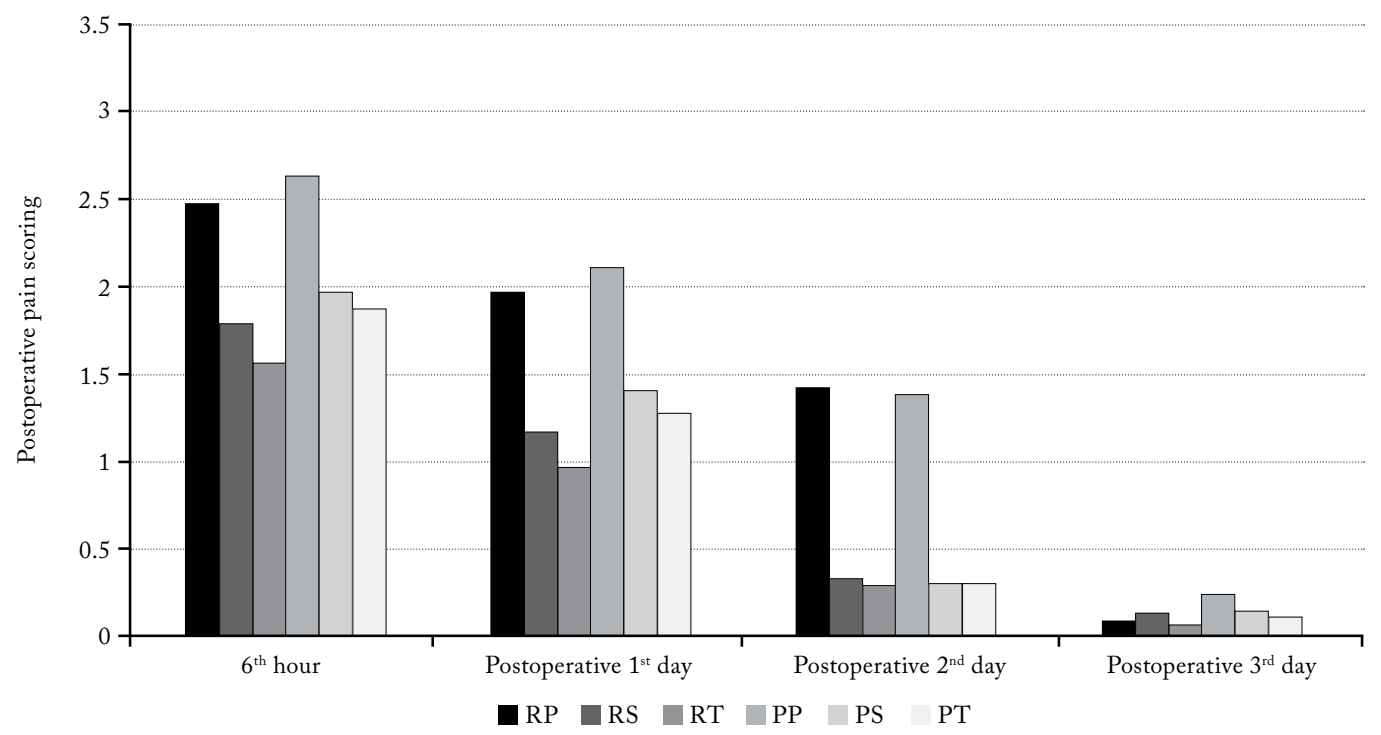

Figure 1. Postoperative pain scores of all study groups. RP: Radiofrequency-Merocel Packing; RS: Radiofrequency-nasal Splint; RT: Radiofrequency-trans-septal suture; PP: Partial inferior turbinectomy-merocel packing; PS: Partial inferior turbinectomy-nasal splint; PT: Partial inferior turbinectomy-trans-septal suture. 
splints and sutures in terms of major hemorrhage, minor hemorrhage, perforation, crusting and hematoma development (Table 3).

The highest pain scores in both RFTA and PIT groups were seen in the Merocel ${ }^{\circledR}$ subgroups and showed a statistically significant difference compared to the other subgroups. Furthermore, suturing subgroups had lower pain scores at all timepoints of the study in both RFTA and PIT groups although these were not statistically significant compared to the splint subgroups. On the third postoperative day evaluation, the highest pain scores were observed in the splint subgroups although these were not statistically significant compared to the other subgroups (Figure 1).

\section{DISCUSSION}

Concurrent multiple nasal surgeries are routine and frequent applications in otolaryngology clinics, and may cause complications more frequently compared to isolated surgeries. Packing, suturing and splints are used to prevent complications that might develop following septoplasty with or without turbinate surgery. ${ }^{[3-6]}$ In this study, we compared the effects of Meroce ${ }^{\circledR}$ nasal packing, septal splints and trans-septal suturing on the prevention of postoperative pain and complications in patient groups after radiofrequency thermal ablation and septoplasty versus patient groups after partial inferior turbinectomy and septoplasty. The PIT groups had more postoperative complications compared to the RFTA groups. The results of our study, in accordance with the literature, showed that the pain scores, postoperative hemorrhage, nasal adherence and crusting levels at all time-points studied were lowering the RFTA group compared to the PIT group. However, PIT is still commonly used at present since it provides effective turbinate reduction and does not require additional equipment. ${ }^{[2,9]}$

Postoperative pain control is quite important for nasal, as for all other surgeries. Nasal packing has the highest level of postoperative pain scores compared to splints and suturing. In different studies comparing postoperative pain levels, packing was shown to have much higher pain scores compared to both trans-septal suturing and splints in the first 48-hour postoperative period until packing was removed. ${ }^{[4-7,10]}$ In this study, the highest pain scores of both RFTA and PIT groups were seen in the Merocel ${ }^{\circledR}$ packing subgroups with a statistically significant difference compared to both splints and suturing. On the third postoperative day evaluation, the highest pain scores were observed in the splint subgroups although these were not statistically significant. The possible cause of this could be that nasal splints had an additive effect on the development of foreign body sensation along with mucosal swelling and crusting that led to nasal discomfort in the postoperative period.

Another important issue after septoplasty is to be able to provide effective hemorrhage control. In studies comparing nasal packing following septoplasty and/or inferior turbinate surgery with trans-septal suturing and nasal splints, it was argued that nasal packing had no superiority in terms of the prevention of postoperative hemorrhage compared to nasal splint and trans-septal suturing. ${ }^{[5-7]}$ Moreover, it was reported that nasal packing could increase hemorrhage following pack removal by causing nasal mucosal injury, and could cause serious hemorrhage that would require pack reapplication. ${ }^{[8]}$ In their study comparing splints, suturing and Merocel $^{\circledR}$ packing after septoplasty, Cayonu et al. $^{[3]}$ reported that there was no difference among these three applications in terms of development of major hemorrhage. In addition, they reported a statistically significant increase in the suturing group in terms of development of minor hemorrhage compared to packing and suturing group. In this study, we also determined that these three applications did not show a statistically significant difference in major postoperative hemorrhage in both RF and PIT groups. Among patients in the RF group, no difference was determined in minor hemorrhage levels between Merocel ${ }^{\circledR}$ packing, splints, and suturing. However, in the PIT groups, minor hemorrhage developed in five patients in the suturing subgroup, three patients in the nasal splint subgroup, and one patient in the Merocel $^{\circledR}$ packing subgroup. Moreover, in the Meroce ${ }^{\circledR}$ packing subgroup, major hemorrhage that required the reapplication of packing developed in two patients following pack removal. The reason for this hemorrhage developing after pack removal could be the mechanical disruption of hemostatic clots.

It was reported in different studies that packing after septoplasty had no superiority in terms of the prevention of postoperative hematoma, perforation and crusting compared to trans-septal suturing and nasal splint application. ${ }^{[4-7]}$ Moreover, the results of our study support the literature by showing that splint, suturing or packing have no statistical superiority over one another in both patient groups in terms of postoperative crusting, hematoma and perforation development.

The highest incidence of intranasal adhesions occurred in patients who had concurrent surgery on both the septum and lateral nasal wall. ${ }^{[1]}$ There are a limited number of studies comparing the efficacy 
of nasal splints, nasal packing and trans-septal suturing techniques in concurrent septoplasty with inferior turbinate surgery in the prevention of nasal synechiae. ${ }^{[12]}$ Some studies comparing these three applications in terms of prevention of synechiae formation after septoplasty argue that splint application is better than other two, while others argue that they have no superiority over one another. In a study of 114 patients, Ardehali and Bastaninejad ${ }^{[5]}$ reported that the difference between patient groups with septal splint and antibiotic mesh versus trans-septal horizontal mattress sutures after septoplasty was statistically insignificant in terms of mucosal adhesion rates. Malki et al. ${ }^{[13]}$ reported that intranasal adhesion developed in the group with splint administration by $1.8 \%$ and in the non-split group by $7.7 \%$ in the sixth week after septoplasty, but this difference was statistically insignificant. Deniz et al. ${ }^{[14]}$ reported a nasal synechiae development rate of $19.7 \%$ in patients with Merocel packing after septoplasty versus 0\% in patients with intranasal splints. In their study of 40 patients in whom only septoplasty was performed, Jung et al. ${ }^{[10]}$ placed silastic splints into one nasal cavity and evaluated the other nasal cavity as control. Both nasal cavities were compared in the first and second week in terms of mucosal status, which was determined to be better in the splint compared to the control side. Also, in our study, nasal synechiae developed in a patient in the Merocel ${ }^{\circledR}$ pack subgroup of RFTA patients, although no statistically significant difference was determined among all three groups in terms of nasal synechiae. This may be explained by the fact that RFTA surgery is a minimally invasive technique that leads to mucosal injury only in needle penetration holes. Furthermore, in this study, nasal synechiae developed in five patients in the Merocel ${ }^{\circledR}$ subgroup and in six patients in the suturing subgroup of PIT. Nasal synechiae developed only in one of the patients in the splint subgroup. A high nasal synechiae rate seen in the PIT group can be explained by the fact that PIT surgery causes extensive mucosal injury. Formation of adhesions was reported in $36.2 \%$ of turbinate resections in the literature. ${ }^{[15]}$ The fact that the nasal synechiae rate was lower in the nasal splint subgroup can be explained by the fact that splints contributed to the prevention of synechiae by preventing mucosal surface contact during recovery. On the other hand, other studies demonstrated increased morbidity such as anxiety of splint removal, pain, discomfort, and rarely, toxic shock syndrome in patients with nasal splints. ${ }^{[16,17]}$ The use of transseptal suturing techniques in minimally invasive inferior turbinate surgeries such as RFTA is believed to be sufficient for the prevention of nasal synechia and other complications, and may be preferable to Meroce ${ }^{\circledR}$ packing. However, the preference for nasal splint application may be considered more appropriate after surgical techniques leading to extensive mucosal surface injuries such as PIT concurrent with septoplasty.

In conclusion, this study has shown that Merocel ${ }^{\circledR}$ packing has no superiority over splint and suture techniques in the prevention of postoperative complications after combined septoplasty and inferior turbinate surgeries and that its pain scores are much higher. Additionally, while suturing techniques and splint application provide equal benefits in the prevention of complications for patients after septoplasty and concurrent RFTA, nasal splint application seems superior in the prevention of nasal synechiae and in postoperative hemorrhage control after PIT surgery. Therefore, we recommend the use of the suturing technique which offers much more comfortable postoperative period to patients compared to the other two techniques after RFTA with septoplasty procedures that are minimally invasive and cause minor mucosal damage. We believe that application of splints would be appropriate in inferior turbinate surgeries such as PIT, which are relatively more invasive and have a higher level of mucosal damage.

\section{Declaration of conflicting interests}

The authors declared no conflicts of interest with respect to the authorship and/or publication of this article.

\section{Funding}

The authors received no financial support for the research and/or authorship of this article.

\section{REFERENCES}

1. Han JK, Stringer SP, Rosenfeld RM, Archer SM, Baker DP, Brown SM, et al. Clinical Consensus Statement: Septoplasty with or without Inferior Turbinate Reduction. Otolaryngol Head Neck Surg 2015;153:708-20.

2. Sapçi T, Sahin B, Karavus A, Akbulut UG. Comparison of the effects of radiofrequency tissue ablation, $\mathrm{CO} 2$ laser ablation, and partial turbinectomy applications on nasal mucociliary functions. Laryngoscope 2003;113:514-9.

3. Cayonu M, Acar A, Horasanlı E, Altundag A, Salihoglu M. Comparison of totally occlusive nasal pack, internal nasal splint, and trans-septal suture technique after septoplasty in terms of immediate respiratory distress related to anesthesia and surgical complications. Acta OtoLaryngologica 2014;134:390-4.

4. Günaydın RÖ, Aygenc E, Karakullukcu S, Fidan F, Celikkanat S. Nasal packing and transseptal suturing techniques: surgical and anaesthetic perspectives. Eur Arch Otorhinolaryngol 2011;268:1151-6. 
5. Ardehali MM, Bastaninejad S. Use of nasal packs and intranasal septal splints following septoplasty. Int J Oral Maxillofac Surg 2009;38:1022-4.

6. Certal V, Silva H, Santos T, Correia A, Carvalho C. Trans-septal suturing technique in septoplasty: a systematic review and meta-analysis. Rhinology 2012;50:236-45.

7. Wadhera R, Zafar N, Gulati SP, Kalra V, Ghai A. Comparative study of intranasal septal splints and nasal packs in patients undergoing nasal septal surgery. Ear Nose Throat J 2014;93:396-408.

8. Acıoğlu E, Edizer DT, Yiğit Ö, Onur F, Alkan Z. Nasal septal packing: which one? Eur Arch Otorhinolaryngol 2012;269:1777-81.

9. Brunworth J, Holmes J, Sindwani R. Inferior turbinate hypertrophy: review and graduated approach to surgical management. Am J Rhinol Allergy 2013;27:411-5.

10. Jung YG, Hong JW, Eun YG, Kim MG. Objective usefulness of thin silastic septal splints after septal surgery. Am J Rhinol Allergy 2011;25:182-5.

11. von Schoenberg M, Robinson P, Ryan R. The morbidity from nasal splints in 105 patients. Clin Otolaryngol Allied
Sci 1992;17:528-30.

12. Asaka D, Yoshikawa M, Okushi T, Nakayama T, Matsuwaki Y, Otori N, et al. Nasal splinting using silicone plates without gauze packing following septoplasty combined with inferior turbinate surgery. Auris Nasus Larynx 2012;39:53-8.

13. Malki D, Quine SM, Pfleiderer AG. Nasal splints, revisited. J Laryngol Otol 1999;113:725-7.

14. Deniz M, Ciftçi Z, Işık A, Demirel OB, Gültekin E. The impact of different nasal packings on postoperative complications. Am J Otolaryngol 2014;35:554-7.

15. White A, Murray JA. Intranasal adhesion formation following surgery for chronic nasal obstruction. Clin Otolaryngol Allied Sci 1988;13:139-43.

16. Hajiioannou JK, Bizaki A, Fragiadakis G, Bourolias C, Spanakis I, Chlouverakis G, et al. Optimal time for nasal packing removal after septoplasty. A comparative study. Rhinology 2007;45:68-71.

17. Wagner R, Toback JM. Toxic shock syndrome following septoplasty using plastic septal splints. Laryngoscope 1986;96:609-10. 